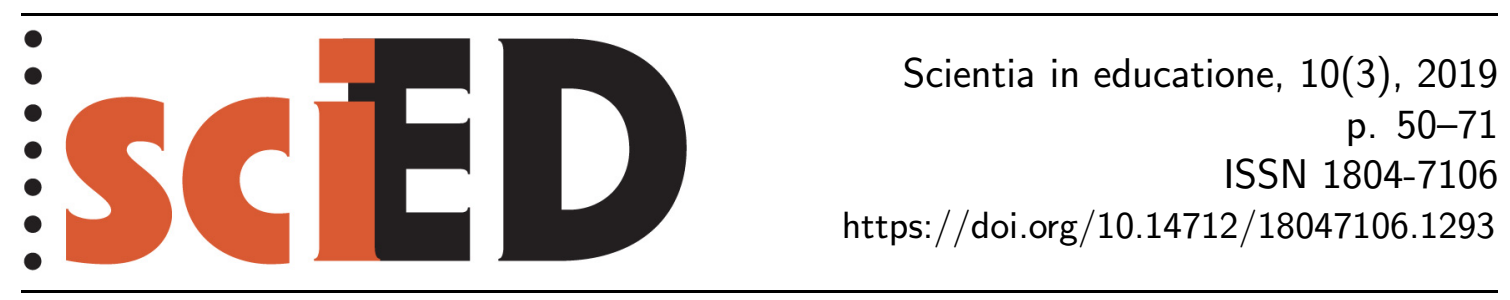

\title{
A Comparative Analysis of the Chemistry Curricula for Lower Secondary Education in the Czech Republic, Poland, Slovenia and Estonia
}

\author{
Eva Stratilová Urválková, Milada Teplá, Svatava Janoušková
}

\begin{abstract}
This article presents an analysis based on the principles of (international) comparative pedagogy focusing on the study of the similarities and differences in subject-specific competences, educational content, and teaching strategies and methods. The analysis focuses on the field of chemistry, specifically the intended curriculum of the abovementioned countries for the level of lower secondary education. Three parameters were monitored and compared: the number of hours allocated for the teaching of chemistry, of all science subjects from the $6^{\text {th }}$ to $9^{\text {th }}$ grades, the educational content of the subject of chemistry and the teaching strategies discussed and/or recommended for the teaching of natural sciences. Analysis has shown that chemistry is taught for the same length of time, but chemistry topics in Slovenia and Estonia are also taught within the subject Natural Sciences in the $7^{\text {th }}$ grade. The expected outcomes are comparable in all countries, but Czech outcomes are grouped into broad topic areas with few outcomes. The expected outcomes from other countries are specified in much more detail. The recommended teaching methods are most closely described in the Slovenian curriculum, which also contains extensive didactic recommendations for individual subjects.
\end{abstract}

Key words: chemistry curriculum, comparative analysis, instruction time, learning outcomes, teaching strategies.

\section{Srovnávací analýza vzdělávacího oboru chemie pro základní školy v rámci českého, polského, slovinského a estonského vzdělávacího programu}

\begin{abstract}
Abstrakt
Cílem článku je představení analýzy vycházející z principů (mezinárodní) srovnávací pedagogiky se zaměřením na zkoumání shod a rozdílů oborově specifických kompetencí, vzdělávacího obsahu (hodinová dotace, rozsah a zaměření učiva) a metod a postupů ve výuce (zařazení hands on aktivity, badatelsky orientované výuky apod.). Analýza se zaměřuje na vzdělávací obor chemie, konkrétně na zamýšlená kurikula shora uvedených zemí pro úroveň nižšího sekundárního vzdělávání. Byly sledovány a porovnávány tři parametry: počet
\end{abstract}


hodin alokovaných pro výuku chemie, popř. všech přírodovědných předmětů od 6 . do 9 . třídy, vzdělávací obsah předmětu chemie a vyučovací metody diskutované a/nebo doporučované pro výuku přírodních věd. Analýza ukázala, že chemie je vyučována stejně dlouhou dobu, ovšem přírodní vědy jsou ve Slovinsku a Estonsku vyučovány v rámci prŕírodovědy už v 6. třídě, přičemž chemická témata jsou součástí kurikula 7. třídy. Očekávané výstupy jsou porovnatelné ve všech zemích, ovšem české výstupy jsou sdružovány do širokých celků s menším počtem výstupů. Očekávané výstupy ostatních zemí jsou mnohem více specifikovány. Doporučované vyučovací metody nejbliže popisuje slovinské kurikulum, které obsahuje také rozsáhlá didaktická doporučení pro jednotlivé předměty.

Klíčová slova: chemické kurikulum, srovnávací analýza, časová dotace, očekávané výstupy, výukové metody.

The national educational system and corresponding documents, especially the national curriculum, have a major influence on the process of education. It is necessary to pay attention to curriculum changes and revisions as they can have farreaching social, political, economic and mostly educational process consequences. The curriculum is continuously updated by minor changes, but major ones have to be prepared thoroughly in their conception as well as in their content so that the consequences for society will be positive. The way of preparing and implementing the updates partly determines the result at schools. The Czech national curricula are called the Framework Educational Programmes (FEP) and after fifteen years of them being in force, revisions for preschools, lower secondary education, general higher secondary and vocational education shall be prepared. The aim is to set a common basis for the individual development of each student by clearly setting the scope and content of education. These changes should provide sufficient time to consolidate the knowledge and skills necessary to achieve the required learning outcomes as well as to develop individual creativity (NUV, 2018). In the process of revision, other educational systems and curricula can be inspiring and useful. From comparison and analysis of the documents results can be drawn that support the preparation and implementation of curricula in the Czech Republic and thus make the process more transparent. Another important aspect is that the updates/revisions of curricula should keep to a similar framework to that which is being implemented in other European countries.

The presented research focuses on chemistry education, for which Polish, Slovenian and Estonian curricula for lower secondary education (ISCED2) were chosen. The choice of the countries was determined intentionally. The intention was to compare the documents of countries that: (1) are successful in international surveys, such as the Programme for International Student Assessment (PISA), and (2) have a similar historical background. From all countries, there are these three (Poland, Estonia and Slovenia) that did better than the Czech Republic in the 2015 PISA testing (OECD, 2016: p. 44). Furthermore, these countries used to be part of the Eastern Bloc of states and/or are Slavic countries. Additionally, Estonia and Poland are countries in which the differences in science literacy results between the schools in the country are under the OECD average, while in the Czech Republic the differences are above the average. Educational systems creating different tracks through the system and allowing students to switch among them tend to have larger differences in between-school performance scores and show an impact of social background on learning outcomes (Blažek \& Př́hodová, 2015: p. 33; OECD, 2016: 
p. 225-226). This means that secondary education in the Czech Republic might be found to be selective and students do not have the same opportunity to achieve the same education since it depends on the school the individuals attend. Another assessed aspect in PISA 2015 testing was collaborative problem solving, where out of the European countries, Estonia (followed by Finland) was the one with the highest score, significantly above the OECD average, while the performance of students from the Czech Republic and Slovenia was not significantly different from this average (OECD, 2016: p. 41).

\section{THEORETICAL FRAMEWORK}

The PISA and also other (inter)national assessment results reflect many aspects of education, that can be additionally more or less analysed. This study is focused on curricula with respect to the ongoing Czech curriculum revisions. Therefore, we aim our attention on aspects that could improve the Czech curriculum, so that it is more relevant for the students' achievement and the teachers' smoother implementation of the content and/or changes into school practice.

One of the most obvious parameters to be compared are learning outcomes and learning content, because "what" is taught constitutes the core of the education. For such comparison qualitative comparative analysis (see, e.g., Mayring, 2000) is mostly used. National curricula, as crucial documents that have an impact on almost everyone, are often under analysis. Therefore, many studies are devoted to curricula, moreover, there are journals that focus on curricula research, such as the Journal of Curriculum Studies, the Curriculum Journal, Transnational Curriculum Inquiry and Curriculum Inquiry.

A variable that could have an effect on students' achievement is instructional time, but it seems not to be independent variable. The results in the Trends in International Mathematics and Science Study (TIMSS) show that one cannot deduce the students' achievement from instructional time spent on education. There are countries that are high performers in science (grade 8) and spend above average instructional time, such as Slovenia, the Russian Federation, Hungary and Lithuania (Martin et al, 2016a, b). On the other hand, there are countries that spend a great deal of time on instruction, but their students perform relatively poorly, under average; these are Malta, Lebanon and Georgia. On the other hand, there are also countries that report an under average number of hours on science instruction, but achieve high results: for example Singapore, England, Ireland and Sweden (Martin et al., 2016a, b). International studies are also ambiguous: Pattal, Cooper and Allen (2010) reviewed this kind of research and concluded there is a small positive or neutral effect in extended school time on the students' achievements. This can be supported by a later three-month experiment done by Meyer and van Klaveren (2013) carried out in seven Dutch elementary schools. On the other hand, there are recent studies confirming the positive effect of instruction time on achievements, such as in mathematics (Jensen, 2013), or a decrease in grade repetition in Indonesian schools (Parinduri, 2014). Andersen, Humlum amd Nandrup (2016) argue that most of the previous studies were performed on small-scale samples and with weak designs, while their study is large-scale and randomised. Their results show a positive impact of increasing instruction time and compare that extra time with no formal requirements on content is at least as efficient as extra time with a detailed teaching programme. Andersen also confirmed previous studies (Duck- 
worth \& Seligman, 2006; Baumeister, 2007) in which extending the school day may cause behavioural problems (students become more aggressive and hyperactive; have trouble managing their emotions), mainly in boys who tend to have less capacity for self-control than girls. However, another large-scale study (about 11500 students) performed in Switzerland (Cattaneo, Oggenfuss \& Wolter, 2017) confirmed a small increase in students' PISA achievements, but the study discusses the effectiveness of this with respect to the high cost that each extra hour brings. Instruction time is important for us, the authors of this article, because it shows how much chemistry education is comparable and whether students have similar time to embrace the required knowledge.

Beside "what" and "how much", there is a crucial question of "how" chemistry content is implemented into chemistry education. The unpopularity of natural sciences is a constant problem that was discussed even at the beginning of the $20^{\text {th }}$ century (Mead, 1906). There are authors that consider the youngsters' interest as a key to successful acceptance of the learning content. Hidi and Renninger (2006) proposed a four-phase model for interest development (triggered situational interest, maintained situational interest, emerging individual interest and well-developed individual interest). They suggested that group work, puzzles, and computers implemented by project-based learning, cooperative group work and tutoring trigger situational interest, and opportunities for intersection and challenges lead to welldeveloped individual interest. Some research discovered that teachers using methods that are responsive, supportive and flexible, are optimal for interest development (Durik \& Harackiewicz, 2007; Reeve, 2002). Teaching methods that are the most preferred by Finnish students in grade 9 and thus may most develop the students' interest, were studied on a sample of 3500 students (Juuti et al., 2010). Boys seemed to be more satisfied with current science teaching, while girls preferred more interactive teaching methods. The structure of the division of teaching methods served as a tool for determining teaching methods in curricula comparison.

The archetypal "how much", "what" and "how" were transformed into research questions for this study:

a) What is the number of hours allocated for chemistry education for each country?

b) What are the topic areas of chemistry learning content in particular national curricula? How do the learning outcomes and content differ?

c) What are recommended teaching methods for chemistry education?

\section{METHODOLOGY}

Based on the principles of comparative education, a comparative analysis of national curricula was chosen as a basic research method. Our approach was qualitative and focused on the comparison of the content (numbers, words, sentences or larger units), not on the quantity of monitored codes. Specifically, the analysis is focused on the educational field of chemistry for lower secondary education (ISCED2). The analysis was performed with official documents, so the explicit (formal) curricula of countries were compared to the Czech national curriculum, the Framework Educational Programme for Elementary Education (FEP EE). Regarding Slovenia and Estonia, the current valid curricula were used for analysis, while for the Polish national curriculum the former valid curriculum, which is related to success in international assessments, was used. 
The list of analysed parameters of national curricula in the educational field of chemistry is below:

a) The number of lessons allocated for chemistry education

b) Topic areas of chemistry learning content

c) Methods and procedures used in chemistry education.

During the analysis of all four curricula, the parts of texts related to parameters $\mathrm{a}, \mathrm{b}$ and $\mathrm{c}$ were coded. Parameter $\mathrm{a}$, the total number of lessons of chemistry (chapter 4.1) is discussed in detail as the total number of lessons for natural science subjects, but our team also put an emphasis on the information of whether there is time allocated for practical laboratory lessons. As a key for coding methods and procedures (parameter c) was used a study by Juuti et al. (2009) which was focused on teaching methods preferences of grade 9 students in Finland. This part of the curriculum analysis uses the same groups of teaching methods as the Finnish study.

The key for coding the topic areas (parameter b) was derived deductively (Mayring, 2000) from the FEP EE. The Czech topic areas, expected learning outcomes and learning content were the independent variables to which other national curricula were compared. In the Czech curriculum, learning content is not compulsory, just recommended, although the key words of learning content were used as a tool for more precise assignment of the Polish, the Slovenian and the Estonian curricula to the Czech document, the FEP EE. The Czech FEP EE is processed too generally and some parts of learning content are involved implicitly in expected outcomes. Therefore, using learning content for valid mutual comparisons of topic areas was a must. All of the ambiguities were discussed in an expert panel of this article's authors so that the objectivity of coding the topic areas would be guaranteed. The table of the reciprocal assignment of the topic areas to each other is part of this article. The nuances and the details of the assignment of the codes are discussed in the next analytical part of this article.

\section{DESCRIPTION OF RESEARCH SAMPLE}

Before the comparative analysis of the national curricula will be described, the countries are briefly presented, mainly with a focus on an overview of their educational systems and the valid documents.

Czechia, the Czech Republic, is a small advanced country (population 10.6 million, January 2017) located in the heart of Europe with a long industrial tradition. The education is organised in kindergartens, basic schools, general and vocational upper secondary schools and institutions of higher education. School attendance starts at the age of 6 and is compulsory for 9 years (additionally, the last year of pre-primary education is compulsory from September 2017). Regarding basic education, primary and lower secondary education is organised mostly within a single-structure system in nine-year basic schools which are divided into the first $\left(1^{\text {st }}-5^{\text {th }}\right.$ grades $)$ and second stage $\left(6^{\text {th }}-9^{\text {th }}\right.$ grades $)$. Lower secondary education is also provided by six- or eight-year general secondary schools and eight-year music and dance conservatoires. Compulsory school attendance, organisation, goals, assessment, etc. are set out in the Act on Pre-Primary, Primary, Secondary, Tertiary Professional and Other Education (the Education Act) (MŠMT, 2004). The national curriculum for basic education is called the Framework Educational Programme for Elementary Education (FEP EE) (VÚP, 2007) which defines the general obligatory framework for all fields of study. Each school elaborates its own School Educational Programme based on the FEP EE where all the content and process details of the 
educational programme are determined. The Education Act and FEP EE are also available in English.

Poland, the Republic of Poland, with its 38.5 million inhabitants is located in Central Europe and is the ninth largest country (by land area) in Europe. In September 2017, a new educational reform began to be implemented. One of its goals is to transform the primary and secondary educational structure into a singlestructure system where the model $6+3$ years turns into a model of an 8-year basic school. Since the results in the PISA reflect the former educational system, we focus on the structure and documents valid until September 2017. The Polish former educational structure consisted of four stages, corresponding to basic education, and was partly compulsory until students were 18 years of age. Stages I and II, related to primary education ("szkoła podstawowa" $1^{\text {st }}-3^{\text {rd }}$ grades and $4^{\text {th }}-6^{\text {th }}$ grades), was followed by stage III organised in junior high school corresponding to lower secondary education $\left(7^{\text {th }}-9^{\text {th }}\right.$ grades, in Polish: "gymnazijm"). The last, stage IV, higher secondary education, took two to four years according to the type of school (Eurydice, 2018a). The former educational system is officially defined in the School Education Act; Polish national curricula are elaborated in special documents that are available on the webpages of the Ministry of National Education. The curriculum for the III and IV stages of education, valid until the 2016/2017 academic year, is available, in Polish (MEN, 2007).

Slovenia, the Republic of Slovenia, is a small country (roughly 2 million inhabitants) located in the south of Central Europe. Compulsory basic education is organised in a single-structure nine-year basic school ("osnovna šola") which has three stages, each for three years. After the second and the third stages (grades 6 and 9 respectively), students write a national assessment in three subjects. The assessments should improve the quality of teaching and learning and they do not influence the annual certificate (Eurydice, 2018b). The organisation of education, the scope, competences, procedure and responsible bodies are determined in the Elementary School Act (MIZS, 2016). The national curriculum is called the "Education Programme" and is available in Slovenian on the webpages of the Ministry of Education and Sport (MIZS, 2018a). In addition to the aims, the programme and the national assessment, there are also curricula for each subject, from which we focused on chemistry (MIZS, 2011a, 2011b). All basic schools provide not just a compulsory, but also an extended basic school programme, including after-school classes, morning care, remedial lessons, supplementary lessons, extracurricular activities, as well as non-compulsory optional subjects (Eurydice, 2018b).

Estonia, the Republic of Estonia, is a small country in Northern Europe, with approximately 1.5 million inhabitants (January 2017). Basic education is also organised in a single-structure system with 9 compulsory grades of basic school ("põhikool"). The primary education has two stages (grades 1-3 and grades 4-6) and children start to go to school at the age of 7 (Eurydice, 2018c). Estonian education is legally determined in the following documents: the different levels of education, including basic education, the principles of management and organisation of the educational system, and compulsory school attendance are defined in the Education Act (HTM, 2018a). The basis of the organisation of study, the principles, the rights and responsibilities of students, parents and school staff and other aspects are described in the Basic Schools and Upper Secondary Schools Act (HTM, 2018b). Finally, the national curriculum for basic schools, from 2011, establishes the values and aims of education, the assessment principles and the syllabi of the subject areas (Government of Estonia, 2011). All of the documents are available in English. 


\section{RESULTS AND DISCUSSION}

\section{TIME ALLOCATED FOR CHEMISTRY EDUCATION}

Czech basic education is mostly organised within a single-structure system in nineyear basic schools. The schools are divided into two stages which correspond to primary and lower secondary education. The second stage, lower secondary education, takes up four grades, from $6^{\text {th }}$ to $9^{\text {th }}$ (ages 11-15). The Framework Educational Programme for Elementary Education defines the minimum time allotment for educational areas or educational fields (FEP EE: p. 106). Physics, chemistry, biology (nature) and geography are all included in the educational area called Man and Nature and the minimum time allotment per week for these subjects all together and for all four grades is 21 lessons. This means there is no official regulation for a subject nor a grade on time allotment, the only rule is to fulfil the total time allotment in four years. Each school defines in its School Educational Programme how the time allotment will be distributed for natural science subjects (or an integrated subject). The usual practice is chemistry is taught in the $8^{\text {th }}$ and $9^{\text {th }}$ grades, in both cases 2 lessons per week. In Table 1 is this is the time allotment for Czech Republic marked as a summary of week lessons for all grades and subjects as it is in the Framework Educational Programme.

Tab. 1: Time allotment per week for natural science subjects

\begin{tabular}{|c|c|c|c|c|c|c|c|c|c|c|c|c|c|c|c|c|}
\hline & \multicolumn{4}{|c|}{ Czech Rep. } & \multicolumn{4}{|c|}{ Poland } & \multicolumn{4}{|c|}{ Slovenia } & \multicolumn{4}{|c|}{ Estonia } \\
\hline Grade & 6 & 7 & 8 & 9 & 6 & 7 & 8 & 9 & 6 & 7 & 8 & 9 & 6 & 7 & 8 & 9 \\
\hline Physics & \multirow{4}{*}{\multicolumn{4}{|c|}{$\sum 21$}} & - & \multicolumn{3}{|c|}{$\sum 4$} & - & - & 2 & 2 & - & $\overline{-}$ & \multicolumn{2}{|c|}{$\sum 4$} \\
\hline Chemistry & & & & & - & \multicolumn{3}{|c|}{$\sum 4$} & - & - & 2 & 2 & - & - & \multicolumn{2}{|c|}{$\sum 4$} \\
\hline Biology & & & & & - & \multicolumn{3}{|c|}{$\sum 4$} & - & - & 1.5 & 2 & - & \multicolumn{3}{|c|}{$\sum 5$} \\
\hline Geography & & & & & - & \multicolumn{3}{|c|}{$\sum 4$} & 1 & 2 & 1.5 & 2 & - & \multicolumn{3}{|c|}{$\sum 5$} \\
\hline Science & - & - & - & - & 3 & - & - & - & 2 & 3 & - & - & 3 & 2 & - & - \\
\hline Total & \multicolumn{4}{|c|}{$\frac{1}{21}$} & \multicolumn{4}{|c|}{$3+16=19$} & \multicolumn{4}{|c|}{$5+18=23$} & \multicolumn{4}{|c|}{$5+18=23$} \\
\hline ISCED level & 2 & 2 & 2 & 2 & 1 & 2 & 2 & 2 & 1 & 2 & 2 & 2 & 1 & 2 & 2 & 2 \\
\hline Chemistry & & & 2 & 2 & & 1 & 2 & 1 & & & 2 & 2 & & & 2 & 2 \\
\hline Laboratory work & \multicolumn{4}{|c|}{$\frac{1}{\text { Not defined }}$} & \multicolumn{4}{|c|}{$\frac{1}{\text { Not defined }}$} & \multicolumn{4}{|c|}{ Not defined } & \multicolumn{4}{|c|}{$\frac{1}{\text { Not defined }}$} \\
\hline
\end{tabular}

Tab. 1 above compares the time allotment for science subjects to the Czech time allotment. The Czech curriculum defines for the educational area Man and Nature 21 hours per week for the whole second stage (grade 6-9, ISCED2). The analysed documents were: the Czech FEP EE (VÚP, 2007: p. 106), the Polish Poradniky dla dyrektora (Kapcia et al.: p. 40, 44-50; Domerecka et al.: p. 30, 32-34), the Slovenian Predmetnik osnovne šole (MIZS, 2018b) and the Estonian National Curriculum for Basic Schools and Natural Science curriculum (Government of Estonia, 2011: p. 12; Pevkur, 2011: p. 2).

Lower secondary education in Poland, Slovenia and Estonia takes three years $\left(7^{\text {th }}-9^{\text {th }}\right.$ grades $)$. If we wish to compare the time spent on natural science in these countries to the Czech curriculum, we have to compare the time spent on studying natural science over four years, from grade 6 to grade 9 . This means we have to consider also the science subject taught in the $6^{\text {th }}$ grade (primary education) in Poland, Slovenia and Estonia. In Poland, the subject Science is studied in the $6^{\text {th }}$ grade 3 lessons per week; in Slovenia and Estonia Science is taught in the $6^{\text {th }}$ and also the $7^{\text {th }}$ grade, parallel to geography and this gives 5 more lessons of natural science (see Tab. 1 above). 
The total number for natural science subjects (physics, chemistry, biology, geography and science) is similar despite some differences between the studied countries. In Poland, students spend 19 lessons per week in grades 6-9 on studying natural science in total, while students in Slovenia and Estonia spend 23 lessons. The Czech Republic with its 21 lessons allocated for natural sciences over the four years is in the middle. Although students in Poland have $17 \%$ less time for natural sciences than students in Slovenia and Estonia, the PISA results do not reflect this.

Regarding chemistry, students in all of the compared countries spend the same amount of time on this subject. In the Czech Republic, the time for the subject chemistry is not specified, but mostly, chemistry is taught two lessons per week for the last two years, in the $8^{\text {th }}$ and $9^{\text {th }}$ grades, which means 4 lessons in chemistry per week per second stage. In Poland, the total number for each subject in each stage of education is defined, which means for chemistry 4 lessons. In Polish schools, chemistry is taught all three years, mostly in the scheme of 1-2-1 lessons. In Slovenia the time schedule for subjects for the whole of basic education is defined; chemistry is studied two lessons per week in the $8^{\text {th }}$ and $9^{\text {th }}$ grades. Lastly, in the Estonian curriculum for Natural Science, it is stated that chemistry, and physics, are studied from the $8^{\text {th }}$ grade for a total of 4 lessons per week, which mostly means the scheme of $2-2$ lessons in the $8^{\text {th }}$ and $9^{\text {th }}$ grades.

None of the compared curricula specifies the time allocated for laboratory practice. In the Czech Republic, laboratory practice during lower secondary education is often performed mostly during chemistry lessons or in two lessons of laboratory practice that are held irregularly or every two weeks.

\section{Chemistry CURRICUlum ANALYsis}

The educational content of chemistry as a school subject is divided into 7 topic areas in the Czech FEP EE. These areas will be first briefly presented and compared to the areas in other countries using a qualitative analysis approach. The table below summarises the topic areas and gives an overview where the intersections of all curricula can be found. The number of expected learning outcomes illustrates how detailed the chemistry curriculum is for each studied country. Moreover, there is a ratio representing how many outcomes out of the total of each compared curricula matches with the Czech curriculum.

The first topic area, Observation, experiment and chemical safety, is devoted to basic laboratory practice, therefore the expected outcomes focus on safe laboratory practice and handling emergency situations. The outcomes are generally described, without any particular suggestions for experiments as it is expected that teachers are continuously applying practical methods. The only explicitly mentioned activities are separation techniques within the second topic Mixtures and $\mathrm{pH}$ measurement within the fifth topic Inorganic compounds. Nevertheless, none of the compared countries isolates the practical work in a special topic area. When discussing the Estonian curriculum: three out of six outcomes from the first topic What does chemistry involve? can be assigned to the Czech Observation, experimentation and safety. These subcategories generally regard laboratory practice: properties of substances, safety regulations and laboratory instruments. Moreover, each Estonian topic area has a part describing practical work and use of ICT containing specific experiments or suggestions for other practical (student-centred) activities. However, there is no suggested laboratory work for the topic areas Atomic structure and periodic table and Amount of substance - mole calculations. Similarly, the Polish chemistry curriculum suggests practical work among the outcomes of each topic 
area, except for the area Internal structure of matter and Carbon and hydrocarbons. The Slovenian list of learning outcomes consists of two parts, the first of which focuses on content knowledge while the other focuses on the process of receiving the knowledge and suggesting methods and activities for fulfilling operational objectives. In this part, there are suggestions for an experimental approach for each topic, in some cases followed by suggested laboratory activities. The only exception is the topic area Amount of substance in which students learn theoretical counting. In the Slovenian chemistry curriculum, safe laboratory practice is among the outcomes of the first topic area Chemistry is a world of substances.

In the second topic area, Mixtures, students are expected to understand basic separation techniques and their theoretical background (solubility, mixtures, mass fraction); air, water and water pollution are also involved. The Czech curriculum is the only one in which the topic of mixtures is separated from the others. In the Polish chemistry curriculum, a concept of mixtures and separation techniques can be found within the topic area Substances and their properties. Unlike the Czech curriculum, the Polish one puts more emphasis on Water and water solutions: it is a special topic area, but the outcomes deal with water as a solvent rather than from the environmental point of view, although the two outcomes (water management and solution saturation) are very similar to Czech outcomes. The Estonian learning outcomes for chemistry education do not contain mixtures and separation techniques. The only outcome regarding solutions and colloids is contained in the first Estonian topic area What does chemistry involve? which correlates with the outcome for Mixtures in the Czech curriculum. Students get to know the concept of the structure of substances and bodies, mixtures and separation techniques in the subject Science which can be found in the Estonian curriculum from the first to the seventh grades. The seventh grade is a part of the third stage of study (ISCED2) and it introduces four topic areas which focus on basic physical, chemical and biological phenomena, as well as technologies and scientific experimental approaches as a part the school subject - Science (Pevkur, 2011). Similarly, the Slovenian chemistry curriculum is lacking the topic of Mixtures because it is a part of another subject, Natural Sciences, taught in the $7^{\text {th }}$ grade. Its first topic area, called Substances, is comprised of topics on chemical elements, mixtures and pure substances, solutions, separation techniques and physical and chemical properties of substances, where students also learn the concept of atomic structure and the periodic table (MIZS, 2011a).

The third topic area, The particulate composition of substances and chemical elements, seems to be the most prevalent in the curricula of all of the compared countries. Three Czech learning outcomes contain these topics: (1) atoms and molecules, (2) chemical elements and chemical compounds, (3) metals vs nonmetals and the periodic table of elements respectively. There are more specific concepts in the learning content. However, the learning content is only a set of recommendations, and therefore it is not obligatory for school practice.

These concepts comprise the structure of the atom (nucleus, electron shell, electrons in reaction), molecules, elements (periodic table, properties, atomic number) and compounds, nomenclature and the essential concept of a chemical bond. The Polish curriculum presents elements vs compound and metal vs non-metal outcomes in the first introductory topic area, while the Internal structure of the atom focuses on the structure of the atom and bonds between atoms in detail. Eight out of fourteen Polish outcomes also match the Czech curriculum. The Slovenian chemistry curriculum contains more information so we can find the concepts of atom-molecule and elements-compounds in the first topic area Chemistry is a world of substances. 
Three outcomes devoted to the history of knowing the structure of the atom and its relations with the periodic table of elements are included in the topic area The Atom and the periodic system of elements. The Slovenian chemistry curriculum defines a separate topic area Chemical bonds, where two outcomes match with the Czech topic area. Additionally, the other outcomes are too specific to claim that they correspond with the Czech curriculum. Three other outcomes regarding properties of elements reflecting the position in the periodic system and characteristics of metals can be found in the fifth Slovenian topic area Elements in the periodic table. Finally, the Estonian curriculum: the second topic area Atomic structure and the periodic table: composition of substances corresponds to five outcomes regarding the structure of the atom and two regarding chemical bonds (covalent vs ionic). In the Estonian curriculum, metals are defined in the wide, separate topic - Best known metals. As the Czech curriculum is very brief in its description of metals ("recognize selected metals and non-metals and estimate their possible properties", FEP EE: p. 54), we can assume that just two of the Estonian specific learning outcomes about metals meet the content of the Czech curriculum. We also have to state that unlike the others, the Czech curriculum does not contain a concept of isotopes or ions.

Chemical reactions, the fourth topic area, presents outcomes related to the nature of chemical reactions (reactants vs products, classification of chemical reactions, chemical equations), the factors influencing the process of chemical reaction and basic calculations (amount of substance, molar mass; the law of conservation of mass). The Polish topic area Chemical reactions is very similar to its Czech version, with the exception of chemical kinetics which is missing and an indwelling difference between physical phenomenon and chemical reaction which are not included in the Czech curriculum. The Slovenian topic area Chemical reactions is also similar to the Czech (and the Polish) as five out of six outcomes match. However, chemical kinetics is not included and the calculations are specified in the last topic Amount of substance. On the other hand, Slovenian students learn the first concepts of chemical reactions also during the subject Natural Sciences in the $7^{\text {th }}$ grade. The Estonian curriculum classifies chemical reactions within the curriculum of the subject Science, in the $7^{\text {th }}$ grade, where students learn the difference between physical and chemical phenomena and where they also study chemical reactions known from their everyday lives. Chemical kinetics is mentioned among the outcomes of the fifth topic area Best known metals, whereas the calculations of moles and molar mass are involved in the seventh topic area Amount of substance: mole calculations.

The fifth Czech topic area, Inorganic compounds, is framed in three outcomes devoted to: (i) comparing the properties and uses of selected oxides, acids, hydroxides and salts important in practice, (ii) the concept of $\mathrm{pH}$ (scale, measuring $\mathrm{pH}$, neutralisation) and (iii) acid rain. The Polish chemistry curriculum does not include inorganic compounds as an isolated topic. The analysis showed that six out of nine outcomes from the topic Acids and bases correspond to the Czech acid and base outcome. The topic area Salts is defined in six outcomes, but just two out of them match with the Czech curriculum. The Slovenian curriculum defines the topic area Acids, bases and salts where five out of eleven outcomes match with the Czech curriculum - the concept of $\mathrm{pH}$, neutralisation and the importance of acids, bases and salts in everyday life. Lastly, the Estonian curriculum has a topic area called Main classes of inorganic substances, but only two outcomes referring to the description of important compounds and chemical pollution match with the Czech curriculum, the other outcomes in the topic refer to chemical reactions of inorganic compounds, solubility and calculations. Other outcomes corresponding to the Czech 
topic Inorganic compounds can be found in the topic area Oxygen and hydrogen, where two outcomes relate to oxides (nomenclature). And the fourth Estonian topic area, Acids and bases, matches five out of eight outcomes with the Czech outcomes regarding acids and bases.

Organic compounds, which is the sixth topic area, consists of six outcomes regarding properties and applications of hydrocarbons, hydrocarbon derivatives ${ }^{1}$, fossil fuels, photosynthesis and biomolecules (proteins, lipids, carbohydrates; vitamins). The content of the following outcomes specifies that students learn about representatives of significant alkanes, alkenes, alkynes and aromatic hydrocarbons as well as significant alcohols and carboxylic acids as examples of hydrocarbon derivatives. The Polish curriculum divides organic compounds into two topic areas: Carbon and hydrocarbons and Hydrocarbon derivatives. The first topic corresponds to the Czech curriculum in four out of nine outcomes, and these outcomes refer to the classification and properties of hydrocarbons. The topic Hydrocarbon derivatives matches with the Czech curriculum in nomenclature and properties of alcohols and well-known organic acids, properties of lipids, protein composition and carbohydrate composition. This means eight matches out of seventeen learning outcomes. The Slovenian chemistry curriculum discusses organic compounds in three topic areas. The first one, Hydrocarbons and polymers, corresponds with the Czech curriculum in five out of fourteen outcomes - fossil fuels, carbon's ability to form compounds, and properties of hydrocarbons. The other two topic areas are Organic compounds containing oxygen and nitrogen atom(s). Furthermore, four out of thirteen outcomes in the topic area Organic compounds containing oxygen atom(s) belong to functional groups, polysaccharides and alcohols. The topic area Organic compounds containing nitrogen atom(s) matches with the Czech curriculum in four out of ten outcomes - aminogroup, proteins, and the role of proteins in the life of Man. On the other hand, the Estonian curriculum discusses organic compounds mostly in the topic area Carbon and carbon compounds (the structural possibilities of carbon, hydrocarbons in nature, alcohols and carbonic acids). There is only one out of five outcomes, describing carbohydrates, lipids and proteins that is specified in the ninth topic area The role of carbon compounds in nature and carbon compounds as materials.

The last, the seventh, topic area, Chemistry and society, expects students to orient themselves in the theoretical preparation and application of various substances in practice (plastics, detergents, fertilisers, drugs, ... ); students should also learn the basics of the chemical industry and understand materials in the terms of sustainable development. The Polish curriculum seems not to include these outcomes. The Slovenian outcomes corresponding to the Czech curriculum can be found in the topic area Hydrocarbons and polymers: three of fourteen outcomes deal with polymers and derivatives influencing the environment. Regarding the Estonian curriculum there are three out of five learning outcomes included in the topic area The role of carbon compounds in nature which match with the Czech curriculum. These outcomes contain the questions of renewable and non-renewable resources, characterisation of best known metals and sustainable living.

\footnotetext{
${ }^{1}$ The title Hydrocarbon derivates is a routine name used in Czech textbooks for naming the group of hydrocarbon compounds containing other atom(s) beside carbon and hydrogen. It is also a part of the Czech national curriculum, the FEP EE, that was used as a key document for comparison. The Polish curriculum uses the same title - the topic area was originally called Hydrocarbon derivatives (Pochodne węlowodorów). This division is not used in English literature, but this text uses the term to keep and reflect the original (Czech) terminology.
} 
Tab. 2: Chemistry curricula - a comparison of topic areas

\begin{tabular}{|c|c|c|c|c|c|c|c|}
\hline $\begin{array}{l}\text { Czech } \\
\text { Republic }\end{array}$ & 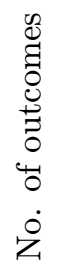 & Poland & 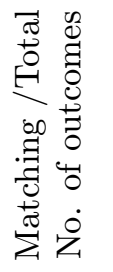 & Slovenia & 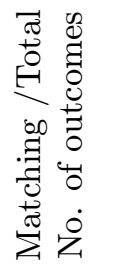 & Estonia & 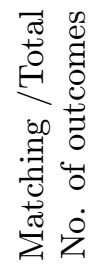 \\
\hline $\begin{array}{l}\text { 1. Observation, } \\
\text { experimenta- } \\
\text { tion and } \\
\text { safety }\end{array}$ & 3 & & & $\begin{array}{l}\text { 1. Chemistry is } \\
\text { a world of } \\
\text { substances }\end{array}$ & $1 / 10$ & $\begin{array}{l}\text { 1. What does } \\
\text { chemistry } \\
\text { involve? }\end{array}$ & $3 / 6$ \\
\hline 2. Mixtures & 6 & $\begin{array}{l}\text { 1. Substances } \\
\text { and their } \\
\text { properties } \\
5 \text {. Water and } \\
\text { water solutions }\end{array}$ & $4 / 8$ & $\begin{array}{l}\text { Science } 7^{\text {th }} \\
\text { grade: } \\
1.1 \text { Substances: } \\
\text { Mixtures and } \\
\text { pure substances } \\
\text { 1.2 Substances: } \\
\text { Solutions }\end{array}$ & & $\begin{array}{l}\text { 1. What does } \\
\text { chemistry } \\
\text { involve? } \\
\text { Science } 7^{\text {th }} \\
\text { grade: } \\
\text { 2. Variability of } \\
\text { substances and } \\
\text { bodies }\end{array}$ & $1 / 6$ \\
\hline $\begin{array}{l}\text { 3. The } \\
\text { particulate } \\
\text { composition of } \\
\text { substances and } \\
\text { chemical } \\
\text { elements }\end{array}$ & 3 & $\begin{array}{l}\text { 1. Substances } \\
\text { and their } \\
\text { properties } \\
\text { 2. Internal } \\
\text { structure of } \\
\text { matter }\end{array}$ & $8 / 14$ & $\begin{array}{l}\text { 1. Chemistry is } \\
\text { a world of } \\
\text { substances } \\
2 . \text { Atom and } \\
\text { periodic system } \\
\text { of elements } \\
\text { 3. Chemical } \\
\text { bond } \\
5 \text {. Elements in } \\
\text { the periodic } \\
\text { system }\end{array}$ & $\begin{array}{l}3 / 7 \\
2 / 8 \\
3 / 10\end{array}$ & $\begin{array}{l}\text { 2. Atomic } \\
\text { structure and } \\
\text { the periodic } \\
\text { table: } \\
\text { composition of } \\
\text { substances } \\
\text { 5. Best known } \\
\text { metals }\end{array}$ & $7 / 8$ \\
\hline $\begin{array}{l}\text { 4. Chemical } \\
\text { reactions }\end{array}$ & 3 & $\begin{array}{l}\text { 3. Chemical } \\
\text { reactions }\end{array}$ & $3 / 4$ & $\begin{array}{l}\text { 4. Chemical } \\
\text { reactions } \\
10 . \text { Amount of } \\
\text { substance } \\
\text { Science } 7^{\text {th }} \\
\text { grade: } \\
\text { 1.4 Substances: } \\
\text { Physical and } \\
\text { chemical } \\
\text { changes in the } \\
\text { substance }\end{array}$ & $\begin{array}{l}5 / 6 \\
3 / 6\end{array}$ & $\begin{array}{l}\text { 5. Best known } \\
\text { metals } \\
\text { 7. Amount of } \\
\text { substance: mole } \\
\text { calculations } \\
\text { Science } 7^{\text {th }} \\
\text { grade: } \\
\text { 3. Natural } \\
\text { phenomena }\end{array}$ & $\begin{array}{l}1 / 8 \\
3 / 6\end{array}$ \\
\hline $\begin{array}{l}\text { 5. Inorganic } \\
\text { compounds }\end{array}$ & 3 & $\begin{array}{l}\text { 6. Acids and } \\
\text { bases } \\
\text { 7. Salts }\end{array}$ & $\begin{array}{l}6 / 9 \\
2 / 6\end{array}$ & $\begin{array}{l}\text { 6. Acids, bases, } \\
\text { salts }\end{array}$ & $5 / 11$ & $\begin{array}{l}\text { 3. Oxygen and } \\
\text { hydrogen: the } \\
\text { most common } \\
\text { compounds } \\
\text { 4. Acids and } \\
\text { bases: } \\
\text { substances of } \\
\text { opposing } \\
\text { properties } \\
6 . \text { Main Classes } \\
\text { of Inorganic } \\
\text { Substances }\end{array}$ & $2 / 6$ \\
\hline
\end{tabular}




\begin{tabular}{|c|c|c|c|c|c|c|c|}
\hline $\begin{array}{l}\text { Czech } \\
\text { Republic }\end{array}$ & 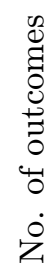 & Poland & 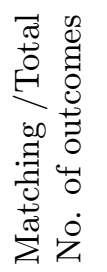 & Slovenia & 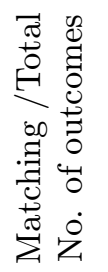 & Estonia & 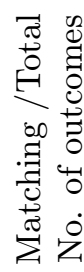 \\
\hline $\begin{array}{l}\text { 6. Organic } \\
\text { compounds }\end{array}$ & 6 & $\begin{array}{l}\text { 8. Carbon and } \\
\text { hydrocarbons } \\
\text { 9. Hydrocarbon } \\
\text { derivatives }\end{array}$ & $\begin{array}{l}4 / 9 \\
8 / 17\end{array}$ & $\begin{array}{l}\text { 7. Hydrocar- } \\
\text { bons and } \\
\text { polymers } \\
\text { 8. Organic } \\
\text { compounds } \\
\text { containing } \\
\text { oxygen atom(s) } \\
\text { 9. Organic } \\
\text { compounds } \\
\text { containing } \\
\text { nitrogen } \\
\text { atom(s) } \\
\end{array}$ & $\begin{array}{l}5 / 14 \\
4 / 13\end{array}$ & $\begin{array}{l}\text { 8. Carbon and } \\
\text { carbon } \\
\text { compounds } \\
\text { 9. The role of } \\
\text { carbon } \\
\text { compounds in } \\
\text { nature and } \\
\text { carbon } \\
\text { compounds as } \\
\text { materials }\end{array}$ & $4 / 8$ \\
\hline $\begin{array}{l}\text { 7. Chemistry } \\
\text { and society }\end{array}$ & 3 & & & $\begin{array}{l}\text { 7. Hydrocar- } \\
\text { bons and } \\
\text { polymers }\end{array}$ & $4 / 14$ & $\begin{array}{l}\text { 9. The role of } \\
\text { carbon } \\
\text { compounds in } \\
\text { nature and } \\
\text { carbon } \\
\text { compounds as } \\
\text { materials }\end{array}$ & $3 / 5$ \\
\hline & & $\begin{array}{l}\text { Topic areas not co } \\
\text { g. Air and other } \\
\text { gases }\end{array}$ & rrespon & $\begin{array}{l}\text { ing with the Cze } \\
\text { 1. Chemistry is } \\
\text { a world of } \\
\text { substances }\end{array}$ & h curri & $\begin{array}{l}\text { llum } \\
\text { 1. What does } \\
\text { chemistry } \\
\text { involve? }\end{array}$ & \\
\hline & & $\begin{array}{l}5 . \text { Water and } \\
\text { water solutions }\end{array}$ & & $\begin{array}{l}\text { 3. Chemical } \\
\text { bond }\end{array}$ & & $\begin{array}{l}\text { 3. Oxygen and } \\
\text { hydrogen: the } \\
\text { most common } \\
\text { compounds }\end{array}$ & \\
\hline & & 7. Salts & & $\begin{array}{l}\text { 10. Amount of } \\
\text { substance }\end{array}$ & & $\begin{array}{l}\text { 5. Best known } \\
\text { metals }\end{array}$ & \\
\hline & & & & & & $\begin{array}{l}\text { 7. Amount of } \\
\text { substance: mole } \\
\text { calculations }\end{array}$ & \\
\hline
\end{tabular}

The Czech topic areas, listed in Tab. 2 above, are a basis for comparison with the curricula of the other countries. The table contains columns with topic areas and columns with a number of learning outcomes for each topic area. The compared curricula have a ratio that corresponds to how many learning outcomes match with the Czech topic area. In the second part of the table there are topic areas that do not match with the Czech curriculum, or match it very loosely.

To summarise the table and description above, we can see that the Czech chemistry curriculum is divided into 7 topic areas with 27 expected learning outcomes, which is less than any of the compared documents. Tab. 3 (below) summarizes the number of topic areas and learning outcomes for four studied countries.

Tab. 3: The total number of topic areas and learning outcomes in chemistry curricula

\begin{tabular}{lcccc}
\hline & Czech Republic & Poland & Slovenia & Estonia \\
\hline Topic areas & 7 & 9 & 10 & 9 \\
\hline Learning outcomes & 27 & 84 & $97(57+40)$ & 62 \\
\hline
\end{tabular}


The Polish curriculum states the outcomes more specifically, therefore there are three times more outcomes. The Slovenian curriculum defines almost four times more outcomes than the Czech one, although the higher number is caused by two parts of outcomes as described above (the content knowledge outcomes and the process knowledge outcomes). There are many topic areas which all four countries include in their curricula. These topic areas are the structure of the atom and the periodic table (topic area 3 in the Czech curriculum), inorganic compounds (topic area 5 in the Czech curriculum), organic compounds (topic area 6 in the Czech curriculum) and partly chemical reactions, even though it is not a separate topic area in the Estonian curriculum. Inorganic compounds in the Czech curriculum correspond to the topic areas acids, bases and salts named in the compared curricula. The Czech topic area organic compounds indicates six outcomes, two of them regarding photosynthesis, which is unique just for the Czech curriculum. The other compared curricula describe biochemical topics dealing with proteins, lipids and carbohydrates apart from photosynthesis. The Polish curriculum defines a special topic area - hydrocarbon derivatives, whereas the Slovenian one contains two topic areas - (i) oxygen and (ii) nitrogen containing hydrocarbon compounds.

Now, we can focus on the differences in detail. The Czech topic area Mixtures corresponds with the first Polish topic area Substances and their properties, but there is a lack of these topics in the Estonian and the Slovenian chemistry curricula as the topics are included in the Natural Science curricula for $7^{\text {th }}$ grade. This means Estonian and Slovenian students meet with this concept sooner than Czech students. Moreover, the Estonian curriculum also presents the concept of chemical reaction sooner, in the $7^{\text {th }}$ grade, as a part of the subject - Natural Sciences. The last topic area in the Czech curriculum, Chemistry and society, focusing on secondary materials (e.g., fertilisers, plastics, drugs), sustainable development and the environment matches with the Estonian topic area The role of carbon compounds in nature and carbon compounds as materials and partly to polymers in the Slovenian curriculum. We can say that this topic area is the most contextualised in the Czech curriculum. The analysis showed there are other contextualised topic areas in the compared curricula: the Polish topic areas Air and other gases and Water and water solutions focus on phenomena regarding gases and water respectively. Another example can be found in the Estonian curriculum which earmarks two topic areas: Oxygen and hydrogen: The Most Common Compounds and The best known metals. These concepts are included in topic areas devoted to inorganic compounds in the curricula of the other countries. The Estonian and the Slovenian curricula also present introductory topic areas (the Estonian What does chemistry involve and the Slovenian Chemistry is a world of substances) that partly relate to the first Czech topic area (Observation, experimentation and safety), but they also point out the significance of chemistry for human life and introductory concepts that students may have met in previous grades. Lastly, one of the most significant differences is that observation and laboratory practice is a separate topic area in the Czech curriculum whereas the other compared countries include these in each topic area.

\section{TEACHING METHODS IN CHEMISTRY EDUCATION}

In this research, the study by Juuti et al. (2009) was used for analysing the teaching methods. Juuti focuses on teaching methods which are preferred by students in the $9^{\text {th }}$ grade. The effectiveness of each method was not considered because the focus was on the development of the students' interest. The teaching methods for

the Finnish study were chosen on the basis of which approaches or strategies are 
introduced in the pre-service teacher education programme at the University of Helsinki, Finland.

Tab. 4 below summarises extracts from the compared national curricula that correspond to each teaching method.

Tab. 4: The total number of topic areas and learning outcomes in chemistry curricula

Strategies in teaching natural science subjects

Teacher-led, large group lecture or dialogue

Czechia Not specified

Poland Not specified

Slovenia Not specified

Estonia Not specified

Small group work

Czechia Not specified

Poland The amount of the teaching content creates many opportunities to work using the educational project method (especially of a research nature), chemical experiments or other activating methods (...). (p. 316)

Slovenia Experimental work should be focused on the individual experimental part of each student (group work, pair work, individual work). (p. 23)

5.1.5 Project collaborative work

Students' social skills are also developed in chemistry classes (the ability to work together, agreeing, expressing ideas, taking into account different views and opinions, etc.) with various activities (...). (p. 25)

Estonia Not specified

\section{Laboratory or practical work}

Czechia The instruction in this educational area is aimed at forming and developing key competences by guiding the student towards:

(1) investigating natural facts and their interconnections while employing various empirical methods of cognition (observation, measurement, experiment) as well as various rational methods. (p. 51)

Poland The student safely uses simple laboratory equipment and basic chemical reagents; designs and conducts simple chemical experiments. (p. 210)

Slovenia Experimental work is the basic teaching method of chemistry education. This work can be combined with other methods such as active learning and teaching. (...) The experimental work should be focused on the individual experimental part of each student (group work, pair work, individual work). (p. 23)

Estonia Through practical work, the students acquire the skills they need for such work: learning how to use safely instruments for experiments and the chemicals necessary in everyday life and assessing the danger of everyday chemicals and materials used in everyday life and technology for human health and the state of the natural environment. (p. 61)

Creative problem solving

Czechia A way of thinking which requires the testing of hypotheses on natural phenomena through several independent methods. (p. 51)

Poland Reasoning and applying the acquired knowledge to solve problems. (p. 210) 
Tab. 4: continue

Slovenia The key characteristics of teaching chemistry is problematic scientific questions and activities that help: students learn about certain concepts, facts, content or solve a problem. (p. 22)

Developing experimental skills and a research approach is very important for introducing students to research work as it enables them to systematically refer to: $(. .$.$) the definition of an experimental$ research problem, the setting up of experimental research questions and the creation of hypotheses or the ability to predict. (p. 23)

Estonia During study, an inquiry-based approach based on the scientific method is used; solving problems arising from the natural, technological and social environments. The studies develop the skills of a creative approach, logical thinking, understanding causal relations, analysis and generalisation. (p. 61)

\section{Reading and writing to learn}

Czechia Not specified

Poland The student acquires and processes information from various sources using information and communication technologies. (p. 210)

The amount of the teaching content creates many opportunities to work using the educational project method (especially of a research nature), a chemical experiment method or other activating methods, which will allow students to acquire and process information in various ways and from different sources. (p. 316)

Slovenia In regards to working with sources, a chemistry teacher teaches students to search, sort, edit, and analyse information, cite sources appropriately, and develop critical thinking; the students will then know how to use, evaluate and present the information they receive properly. (p. 25)

Estonia The students acquire the ability to understand and compile chemistry-related texts, make sense of and use chemistry-related vocabulary correctly, present chemistry-related information through oral and written presentations using different verbal and visual forms of presentation (verbally, and as diagrams, graphs, models and formulas) and using different sources of information, including electronic ones. (p. 61)

\begin{tabular}{ll}
\hline Out-of-school informal learning \\
\hline Czechia & Not specified \\
\hline Poland & $\begin{array}{l}\text { During the third stage of education, chemistry teachers should find time } \\
\text { to perform experiments, use student-centred methods, create } \\
\text { educational projects and provide excursions for students. (p. 316) }\end{array}$ \\
\hline Slovenia & $\begin{array}{l}\text { The chemistry teacher should include modern findings in chemistry; } \\
\text { a source of information can also be excursions to research institutions, } \\
\text { etc. }\end{array}$ \\
\hline $\begin{array}{l}\text { Estonia } \\
\text { The school provides: (...) 5) outdoor learning sessions and the students } \\
\text { participate in nature and environmental education projects. In the } 2^{\text {nd }}\end{array}$ \\
stage of study the students, at least twice, take part in an environmental \\
centre or science education initiative outside of the school and in the $3^{\text {rd }}$ \\
stage of study in every science subject once during the academic year (in \\
the natural environment, at a museum, in a laboratory). (p. 8)
\end{tabular}


The Czech FEP EE does not specify any teaching method recommended for natural science education. Nevertheless, each subject or topic area is described at the beginning and the main objectives are listed. In the Czech objectives for the educational area Man and Nature, we can see suggestions for laboratory work and creative problem solving.

The former Polish curriculum lacks a description of each subject. On the other hand, educational goals for each subject are included in the introduction. Chemistry has three goals - one of them being managing practical work. At the end of the document, there are short recommendations for implementation, and for chemistry, experiments, activating methods, educational projects (that often require group work) and excursions are mentioned. The new national curriculum that started to be implemented in September 2017 did not change chemistry content and the expected outcomes a great deal, but a remarkable change was in the description of didactic recommendations - problem-based education is stressed and particular experiments are recommended (MEN, 2018).

Regarding methods, the Slovenian chemistry curriculum is the most descriptive. At the beginning of the document, there is a summary of general objectives comprised of experimental skills and critical thinking. Another supportive tool is defining the process of knowledge within the framework of the expected learning outcomes of each topic area. These outcomes recommend an experimental, practical, research and theoretical (such as models, visualisations) approach and other tips for chemistry education. Moreover, the last chapter of the chemistry curriculum is devoted to didactic recommendations (p. 22-31). The main emphasis is put on experimental and practical student-centred activities that should be the main teaching methods in chemistry education. Additionally, various kinds of information and communication technologies, such as visualisation elements, chemical models, and animations should be used to support chemical literacy and the integration of the macroscopic, submicroscopic and symbolic levels. The use of the internet and ICT is also recommended for students' work with information sources, critical thinking and presentation of a scientific issue (p. 25). Teachers should also speak about current knowledge in chemistry that could be supported by excursions to research institutions.

The Estonian curriculum for natural science is the only one naming specific teaching methods which can be used in education for all natural science subjects in the introduction chapter. Unfortunately, the list given for using active learning methods in classes does not contain any suggestions on how to implement the methods in education. A physical learning environment is also specified in the general introductory part, including out-of-school learning (p. 8). Other teaching methods can be found in the description of chemistry (p. 61-62): students learn basic laboratory practice, solve problems by logical thinking, and learn analysis and generalisation and the understanding of chemistry-related texts which they can interpret and present with the proper terminology.

If we compare the four curricula, the Czech and the Polish ones are very brief regarding teaching methods, although the methods can be implicitly derived from the descriptions. The same is implicitly provided in the description in the other (Slovenian and Estonian) curricula, although the Slovenian one is the most elaborated and suggests tips for teaching within each topic area. 


\section{CONCLUSION}

The Czech national curricula, the Framework Educational Programmes, for different levels of education, have been under revision. The National Institute for Education, with its panel of experts, is working on the preparation of changes that in addition to other changes shall keep a similar framework as the curricula of other countries. A comparison of the national curricula of other countries is therefore an essential part for suggesting relevant changes. For these purposes countries were chosen that have higher achievements in PISA testing and have a similar historical background as the Czech Republic: Poland, Slovenia and Estonia. The curricula were analysed using the comparative analysis method in aspects of instructional time, teaching methods and learning content.

This study is focused on the chemistry curriculum, therefore the analysed documents were the current Czech, Slovenian and Estonian chemistry curriculum as a part of the national curriculum. Regarding Poland, the former national curriculum for the III and IV stages was used because this curriculum is reflected in the PISA results.

Three research questions were studied: (1) What is the number of hours allocated for chemistry education for each country?, (2) What are the topic areas of chemistry learning content in particular national curricula? How do the learning outcomes and content differ?, (3) What are recommended teaching methods for chemistry education?

Our findings show that regarding the instruction time for chemistry education, all four countries are nearly the same: chemistry is taught four hours per week for the entire length of study, which means two lessons in $8^{\text {th }}$ and $9^{\text {th }}$ grade except for Poland where it is often taught in grades 7, 8 and 9 (1-2-1 lessons). The difference was revealed in the total number of hours allocated for science subjects in grades 6 to 9. Slovenian and Estonian students study natural science subjects the most frequent (total number: 23 hours), while Czech students study natural science $9 \%$ less (total number: 21 hours) and Polish students even 17\% less (total number: 19 hours) than in Slovenia and Estonia. The in-depth comparative analysis of national chemistry curricula discovered that there are no radical differences in the chemistry content. The documents differ in the attention to detail that can be seen in a number of learning outcomes stated in each chemistry curriculum. The Czech chemistry curriculum defines 7 big topic areas, whereas Poland and Estonia define 9 and Slovenia 10 topic areas. The most obvious differences are then the numbers of learning outcomes: Czech chemistry content is defined in 27 outcomes, Estonian in 62 (2.3 times more), Polish in 84 (3.1 times more) and Slovenian chemistry content is stated in 57 content knowledge and 40 process knowledge outcomes (together, 3.6 times more). A closer qualitative analysis of the documents showed that the Czech learning outcomes are extensive, but also vague at the same time. The learning content that in the Czech curriculum is only recommended had to be considered for precise assignment in other countries' learning outcomes. Often, more learning outcomes of foreign curriculum were assigned to Czech corresponding outcomes - in other words Polish, Slovenian and Estonian learning outcomes are more elaborated and specific which can lead to easier implementation of particular topics into chemistry education.

The last analysed parameter was teaching methods recommended in the chemistry curricula. The least accompanying information is provided by the Polish curriculum even though there are passing references to some methods. The Czech curriculum introduces the educational area Man and Nature and provides informa- 
tion on goals and methods, but not in detail. The Estonian chemistry curriculum is more descriptive, but the most elaborated curriculum regarding the information on implementation of the chemistry curriculum is the Slovenian one. For each topic area there are stated learning outcomes focused on methods and approaches that can be used, moreover there is a detailed chapter on didactic recommendations that describes the conditions for laboratory courses, use of information and communication technologies and detailed cross-curricular links.

Our comparative analysis focused on four chemistry curricula, Czech, Polish, Slovenian and Estonian. The results show that the time for chemistry lessons is comparable in all four countries. Chemistry content corresponds, with no principal differences, but Polish, Slovenian and Estonian learning outcomes are defined in much more detail. Finally, the Estonian, and mainly the Slovenian, chemistry curricula, offer more details for chemistry education, especially the Slovenian didactic recommendations. We can conclude the PISA results may not reflect chemistry content, which is almost the same for all four compared countries. The difference is apparently in the implementation of the chemistry curriculum in practice, which cannot be analysed from the official documents. But, at least it seems, a more elaborated chemistry curriculum can be a more useful and more powerful tool for chemistry teachers who will know also "how" and not just "what" is to be taught in chemistry lessons.

\section{ACKNOWLEDGEMENT}

This work has been supported by Charles University Research Centre programme No. UNCE/HUM/024.

\section{REFERENCES}

Andersen, S. C., Humlum, M. K. \& Nandrup, A. B. (2016). Increasing instruction time in school does increase learning. Proceedings of the National Academy of Sciences of the United States of America, 113(27), 7481-7484. https://doi.org/10.1073/pnas.1516686113

Baumeister, R.F., Vohs, K. D. \& Tice, D. M. (2007). The strength model of self-control. Current Directions in Psychological Science, 16(6), 351-355. https://doi.org/10.1111/j.1467-8721.2007.00534.x

Blažek, R. \& Př́hodová, S. (2016). Mezinárodní šetření PISA 2015: národní zpráva, př́rodovědná gramotnost. Praha: Česká školní inspekce. Retrieved from https://www.csicr.cz/cz/Dokumenty/Publikace/Narodni-zprava-PISA-2015

Cattaneo, M. A., Oggenfuss, Ch. \& Wolter, S. C. (2017). The more, the better? The impact of instructional time on student performance. Education Economics, 25(5), 433-445. https://doi.org/10.1080/09645292.2017.1315055

Domerecka, B., Leśniewska, I., Sikora, R. \& Tałan, P. (2008). Poradnik dla dyrektora szkoty podstawowej - ramowe plany nauczania. Warszawa: Ośrodek Rozwoju Edukacji. Retrieved from http://www.bc.ore.edu.pl/Content/268/ poradnik_dla_dyrektora_sp_ramowe_plany_nauczania.pdf

Duckworth, A.L. \& Seligman, M. E. P. (2006). Self-discipline gives girls the edge: Gender in self-discipline, grades, and achievement test scores. Journal of Educational Psychology, 98(1), 198-208. https://doi.org/10.1037/0022-0663.98.1.198 
Durik, A. M. \& Harackiewicz, J. M. (2007). Different strokes for different folks: How individual interest moderates the effects of situational factors on task interest. Journal of Educational Psychology, 99(3), 597-610. https://doi.org/10.1037/0022-0663.99.3.597

Eurydice. (2018a). Poland overview. Retrieved from https://eacea.ec.europa.eu/national-policies/Eurydice/content/poland_en

Eurydice. (2018b). Slovenia overview. Retrieved from https://eacea.ec.europa.eu/national-policies/Eurydice/content/slovenia_en

Eurydice. (2018c). Estonia overview. Retrieved from https://eacea.ec.europa.eu/national-policies/Eurydice/content/estonia_en

Government of the republic of Estonia. (2011). National curriculum for basic schools Regulation. Tallin. Retrieved from https://www.hm.ee/sites/default/files/est_basic_school_nat_cur_2014_general_part_1.pdf

Hidi, S. \& Renninger, K. A. (2006). The four-phase model of interest development. Educational Psychologist, 4(2), 111-127. https://doi.org/10.1207/s15326985ep4102_4

HTM (The Ministry of Education and Research). (2018a). Republic of Estonia education act. Retrieved from https://www.riigiteataja.ee/en/eli/ee/526082014004/consolide/current

HTM (The Ministry of Education and Research). (2018b). Basic schools and upper secondary schools act. Retrieved from:

https://www.riigiteataja.ee/en/eli/530102013042/consolide

Jensen, V. M. (2013). Working longer makes students stronger? The effects of ninth grade classroom hours on ninth grade student performance. Educational Research, 55(2), 180-194. https://doi.org/10.1080/00131881.2013.801244

Juuti, K. \& Lavonen, J., et al. (2010). Science teaching methods preferred by grade 9 students in Finland. International Journal of Science and Mathematics Education, 8(4), 611-632. https://doi.org/10.1007/s10763-009-9177-8

Kapcia, A., Kulesza, D. \& Rudnik, J. (2008). Poradnik dla dyrektora gimnazjum ramowe plany nauczania. Warszawa: Ośrodek rozwoju edukacji. Retrieved from http://www.bc.ore.edu.pl/Content/269/ poradnik_dla_dyrektora_gimnazjum_ramowe_plany_nauczania.pdf

Martin, M. O., Mullis, I. V.S., Foy, P. \& Hooper, M. (2016a). Instructional time spent on science. TIMSS 2015 International results in science. Retrieved from http://timss2015.org/timss-2015/science/classroom-instruction/ instructional-time-spent-on-science/

Martin, M. O., Mullis, I. V.S., Foy, P. \& Hooper, M. (2016b). Distribution of science achievement. Instructional time spent on science. TIMSS 2015 international results in science. Retrieved from http://timss2015.org/timss-2015/science/student-achievement/ distribution-of-science-achievement/

Mayring, P. (2000). Qualitative content analysis. Retrieved from http://www.qualitativeresearch.net/index.php/fqs/article/view/1089

Mead, G.H. (1906). Teaching of science in college. Science, 24(613), 390-397. https://doi.org/10.1126/science.24.613.390

MEN (Ministry of National Education of Poland). (circa 2007). Podstawa programowa (III i IV etapie). Retrieved from https://men.gov.pl/wp-content/uploads/2011/02/zalaczniknr4.pdf 
MEN (Ministry of National Education of Poland). (2018). Podstawa programowa, skola podstawowa, Chemia. Retrieved from

https://podstawaprogramowa.pl/Szkola-podstawowa-IV-VIII/Chemia

Meyer, E. \& van Klaveren, C. (2013). The effectiveness of extended day programs:

Evidence from a randomized field experiment in the Netherlands. Economics of

Education Review, 36(4), 1-11. https://doi.org/10.1016/j.econedurev.2013.04.002

MIZS (Ministry of Education, Science and Sport of the Republic of Slovenia). (2018a).

The education programme. Retrieved from http:/www.mizs.gov.si/si/delovna_podrocja/ direktorat_za_predsolsko_vzgojo_in_osnovno_solstvo/osnovno_solstvo/

MIZS (Ministry of Education, Science and Sport of the Republic of Slovenia). (2018b). Predmetnik osnovne šole. Retrieved from

http://www.mizs.gov.si/fileadmin/mizs.gov.si/pageuploads/podrocje/os/devetletka/ predmetniki/Pred_14_OS_4_12.pdf

MIZS (Ministry of Education, Science and Sport of the Republic of Slovenia). (2011a). Program osnovna šola. Naravoslovje - učni načrt. Ljubljana: MIZS. Retrieved from http://www.mizs.gov.si/fileadmin/mizs.gov.si/pageuploads/podrocje/os/prenovljeni_UN/ UN_naravoslovje.pdf

MIZS (Ministry of Education, Science and Sport of the Republic of Slovenia). (2011b). Program osnova šola. Kemija. Učni načrt. Ljubljana. Retrieved from http://www.mizs.gov.si/fileadmin/mizs.gov.si/pageuploads/podrocje/os/prenovljeni_UN/ UN_kemija.pdf

MIZS (Ministry of Education, Science and Sport of the Republic of Slovenia). (2016). Organisation and financing of education act. Slovenia. Retrieved from http://www.mizs.gov.si/fileadmin/mizs.gov.si/pageuploads/ANG/ Organisation_and_Financing_of_Education_Act_Oct_2016.pdf

MŠMT (Ministry of Education, Youth and Sports). (2004). Act no. 561/2004 collection of law, on pre-school, basic, secondary, tertiary professional and other education (the education act). In Sbirka zákonů ČR. Retrieved from http://www.msmt.cz/uploads/soubory/IMzakon561ponovelach.pdf

NÚV (National Institute for Education). (2018). Development of education. Retrieved from http://www.nuv.cz/our-work/development

OECD (Organisation for Economic Co-operation and Development). (2016). PISA 2015 Results (volume I): excellence and equity in education, PISA, Paris: OECD Publishing. https://doi.org/10.1787/9789264266490-en

Parinduri, R. A. (2014). Do children spend too much time in schools? Evidence from a longer school year in Indonesia. Economics of Education Review, 41(2014), 89-104. https://doi.org/10.1016/j.econedurev.2014.05.001

Patall, E., Cooper, H. \& Allen, A. (2010). Extending the school day or school year. Review of Educational ResearchI, 80(3), 401-436.

https://doi.org/10.3102/0034654310377086

Pevkur, H. (2011). Appendix 4 of regulation no. 1 of the government of the republic of Estonia - subject field: natural science. Retrieved from https://www.hm.ee/sites/default/files/est_basic_school_nat_cur_2014_appendix_4_final.pdf

Reeve, J. (2002). Self-determination theory applied to educational settings. In E. L. Deci \& R. M. Ryan (Eds.), Handbook of self-determination research (183-203). Rochester, NY, US: University of Rochester Press. 
VÚP (Research Institute of Education). (2007). Framework educational programme for elementary education. Prague. Retrieved from http://www.nuv.cz/file/195

Eva Stratilová URVÁlKovÁ, urvalkov@natur.cuni.cz

Milada TePlÁ, milada.tepla@natur.cuni.cz

SvATAVA JANOUŠKOVÁ, svatava.janouskova@natur.cuni.cz

Charles University, Faculty of Science

Department of Teaching and Didactics of Chemistry

Albertov 3, 12843 Prague 2, Czech Republic 